\title{
Carrot Seed Germination at High Temperature: Effect of Genotype and Association with Ethylene Production
}

\author{
Warley M. Nascimento ${ }^{1}$, Jairo V. Vieira ${ }^{1}$, and Giovani O. Silva ${ }^{1}$ \\ Embrapa Vegetables, C.P. 218, 70359-970 Brasilia-DF, Brazil
}

Kathleen R. Reitsma ${ }^{2}$

Iowa State University, North Central Regional Plant Introduction Station, Ames, IA 50011-1170

\section{Daniel J. Cantliffe $\mathrm{j}^{\mathbf{3}, \mathbf{4}}$ \\ Horticultural Sciences Department, Institute of Food and Agricultural Sciences, University of Florida, 1251 Fifield Hall, P.O. Box 110690, Gainesville, FL 32611-0690}

Additional index words. Daucus carota L., thermotolerance, stand establishment, vigor, cultivars, germplasm

\begin{abstract}
Carrot (Daucus carota L.) seed germination may be erratic or reduced under high temperatures (above $35^{\circ} \mathrm{C}$ ). Even in tropical genotypes (tolerant to high temperatures during crop development), the negative effects of high temperatures on carrot stand establishment have been observed, especially during summer. The objectives of this study were to characterize commercial carrot cultivars and accession lines for their ability to germinate at high temperature and determine the ethylene production during imbibition at high temperature. Seeds from 34 commercial cultivars and 125 carrot accessions from the North Central Regional Plant Introduction Station were germinated at $25^{\circ} \mathrm{C}$ (optimal) and $35 \pm 0.5^{\circ} \mathrm{C}$ (high) in constant light. Ethylene production during seed imbibition at high temperature was evaluated in some genotypes. Many of the commercial cultivars had reduced germination at $35{ }^{\circ} \mathrm{C}$. 'XPC-3617', 'Alvorada', 'Brasilia', and 'Esplanada' had the greatest germination at $35^{\circ} \mathrm{C}$. A greater number of accessions germinated at $35^{\circ} \mathrm{C}$ than did the commercial genotypes. The accession PI 319858 germinated $95 \%$ at both temperatures and was considered thermotolerant. Six accessions (Ames 7665, Ames 7698, Ames 25031, PI 167082, PI 294637, and PI 319858) germinated above $80 \%$ at $35{ }^{\circ} \mathrm{C}$ and were also identified as potential sources of thermotolerance. Fifteen other accessions (Ames 7694, Ames 25031, Ames 25036, Ames 25049, Ames 25705, PI 167082, PI 179687, PI 180834, PI 261782, PI 269486, PI 273658, PI 277710, PI 288242, PI 294637, and PI 319858) had thermotolerance ratios of T35/T25 0.85 or greater (where $\mathrm{T35}=$ germination at $35^{\circ} \mathrm{C}$ and $\mathrm{T} 25=$ germination at $25^{\circ} \mathrm{C}$ ) and were identified for further testing. The identified thermotolerant genotypes might be useful for carrot seed germination mechanism studies as well as for breeding programs. Ethylene production during seed germination at high temperature was greater in thermotolerant genotypes than in thermosensitive genotypes. High correlations were observed between first germination count at $35^{\circ} \mathrm{C}$ and ethylene production, total germination at $35^{\circ} \mathrm{C}$ and ethylene production, and thermotolerance ratio and ethylene production.
\end{abstract}

Carrot crops are established by direct seeding, and poor stands may occur when sowing is done during extremely low or high temperatures. Many publications relate the negative effects of low temperature on carrot stand establishment (Cantliffe and Elballa, 1994; Corbineau et al., 1994; Nascimento and Pereira, 2007; Pereira et al., 2007; Vieira

\footnotetext{
Received for publication 17 Dec. 2007. Accepted for publication 2 Apr. 2008.

We thank the CNPq for financial support, process no. 470782/2004-8.

${ }^{1}$ Research Scientist.

${ }^{2}$ Curator.

${ }^{3}$ Distinguished Professor and Chair.

${ }^{4}$ To whom reprint requests should be addressed; e-mail djcant@ufl.edu
}

et al., 2005). However, high temperatures (35 to $40^{\circ} \mathrm{C}$ ) may also delay or inhibit carrot seed germination in the field and reduce uniformity and total stand establishment (Cantliffe and Elballa, 1994; Nascimento and Pereira, 2007). In tropical areas, carrot production is vulnerable to loss from thermal stress (heat) during stand establishment (Vieira et al., 2005), and most commercial carrot cultivars have reduced seed germination at high temperatures (Pereira et al., 2007). Carrot seeds germinate over a range from 10 to $35{ }^{\circ} \mathrm{C}$ (Rubatzky et al., 1999) with an optimal range of 25 to $30{ }^{\circ} \mathrm{C}$ (Corbineau et al., 1994). The Association of Official Seed Analysts recommends an alternating day/night regimen of 30 to $20^{\circ} \mathrm{C}(8 / 16 \mathrm{~h})$ as the standard protocol for carrot seed germination tests (Association of Official Seed Analysts, 1993).
Superior genetic resources are required to reduce the risk of loss from high temperature stress. Within the carrot collection of the USDA-ARS, located in Ames, IA, there are 1129 accessions in the NPGS Daucus collection with 893 accessions available for distribution (K. Reitsma, personal communication). Germplasm characterization is an important function of a gene bank, and knowing the morphological and agronomic traits as well as their reaction to biotic and abiotic stresses in the individual accessions increases the potential usefulness of the germplasm collection (Day-Rubenstein et al., 2006).

Carrot cultivars differ in their sensitivity to high temperatures during seed germination (Pereira et al., 2007). One approach to improve thermotolerance (ability of seed to germinate at high temperature) is to transfer superior alleles from intrinsically thermotolerant wild relatives to less tolerant commercial cultivars (Senthil-Kumar et al., 2007). However, the genetic variation in thermotolerance among cultivated carrot gene bank accessions has not been determined (P. Simon, personal communication).

Thermotolerance in seeds is typically a multigenic trait (Senthil-Kumar et al., 2007), and there is no known thermotolerance mechanism in carrot. In lettuce, quantitative trait loci analysis may provide a new approach for elucidating the physiological factors controlling the imposition and release of seed thermoinhibition (Argyris et al., 2005). Tolerance to high temperatures during germination would seem to require constitutive genetic effects, although the mother-plant environment during seed development and maturation can also affect carrot seed quality (Gray et al., 1988) and influence thermotolerance as observed in other species (Sung et al., 1998). Also, tolerance to high temperatures during seed germination and early seedling growth involves acclimation effects such as synthesis of heat-shock proteins (Vierling, 1991). Oxygen requirements for seed germination may also be modulated by temperature (Bradford et al., 2007), and high temperatures during carrot seed imbibition may affect sensitivity to low oxygen tensions (Corbineau et al., 1994).

High seed vigor is necessary for tolerance to environmental stress (Heydeker, 1972), including high temperatures. For example, improved seedling emergence and uniformity of preconditioned lettuce seeds at high temperature was related to high vigor (PerkinsVeazie and Cantliffe, 1984). Examining two lettuce genotypes, these authors found that priming prevented thermodormancy in unaged but not in aged lettuce seeds. Seed aging can lead to some physiological and biochemical changes such as reduced ethylene and endo- $\beta$-mannanase activity and thus lead to thermoinhibition in germination, as observed in lettuce seeds (Nascimento et al., 2005).

The role of ethylene in seed germination has been extensively studied in several species (Abeles et al., 1992). In lettuce, it has 
been suggested that ethylene is necessary for germination at supraoptimal temperatures (Kozareva et al., 2004, 2006; Nascimento et al., 2000, 2004). The involvement of ethylene in carrot seed germination, especially under stress conditions, has not been studied.

The objectives of this study were to characterize commercial carrot genotypes and screen germplasm to identify lines with greater tolerance to germinate at high temperatures and then to determine if there is a possible correlation between ethylene production and seed germination at high temperatures.

\section{Materials and Methods}

\section{Germination at high temperature of carrot cultivars from various commercial sources}

Plant material. Seeds of 34 commercial carrot genotypes (hybrids and OP varieties) were used in this study (Table 1).

Germination test. Three replications of 25 seeds were placed in $5.5-\mathrm{cm}$ petri dishes with two layers of 4.5-cm diameter \#3 filter paper (Anchor Paper Co., St. Paul, MN) moistened with $4 \mathrm{~mL}$ of distilled water. Additional distilled water was added as needed to keep the filter paper moist. Seeds were incubated under constant light $\left(30 \mu \mathrm{mol} \cdot \mathrm{m}^{-2} \cdot \mathrm{s}^{-1}\right)$ in Precision Scientific (Winchester, VA) incubators at $25{ }^{\circ} \mathrm{C}$ (optimal) and $35 \pm 0.5{ }^{\circ} \mathrm{C}$ (adverse). Germination was defined as visible radicle protrusion through the seedcoat and was evaluated after 5 (first count) and 10 (final count) $d$ of incubation. A thermotolerance ratio $(T 35 / T 25$, where $T 35=$ germination at $35{ }^{\circ} \mathrm{C}$, supraoptimal and $T 25=$ germination at $25{ }^{\circ} \mathrm{C}$, optimal) was created to minimize possible errors from using seeds with low viability overall.

Seed mass. Three replications of 100 seeds were weighed on an analytical scale to the nearest milligram.

Statistical analysis. Analysis of variance was performed with the Genes Program (Cruz, 2001), and the characters of first count, total germination, and the ratio of T35/T25 were transformed by $(x+0.50)^{1 / 2}$ to attend the normality presupposition of Lilliefors' (1967) test. The means were compared with the Scott and Knott (1974) test, and simple correlations between character pairs were calculated.

\section{Screening carrot germplasm for seed germination at high temperature}

Seeds from the Introduction Station (NCRPIS), located in Ames, IA, part of the U.S. National Plant Germplasm System, were used in this study. The accessions were selected according to seed quality (only the accessions that were regenerated in recent years and under like environmental conditions and protocols were used). Also included were a few accessions in which the donor (Korea) noted the accessions to have tolerance to high temperatures.

Germination test. Three replications of 20 seeds were incubated by using the same procedures as described previously for commercial seed samples.

Statistical analysis. The data from the $25{ }^{\circ} \mathrm{C}$ germination test were transformed by

Table 1. Analysis of variance and comparison of means for seed mass (SM), first germination count at $25^{\circ} \mathrm{C}(\mathrm{FC} 25)$, total germination at $25{ }^{\circ} \mathrm{C}$ (TG25), first germination count at $35^{\circ} \mathrm{C}(\mathrm{FC} 35)$, total germination at $35^{\circ} \mathrm{C}$ (TG35), and thermotolerance ratio $(T 35 / T 25)$ from 34 commercial carrot cultivars

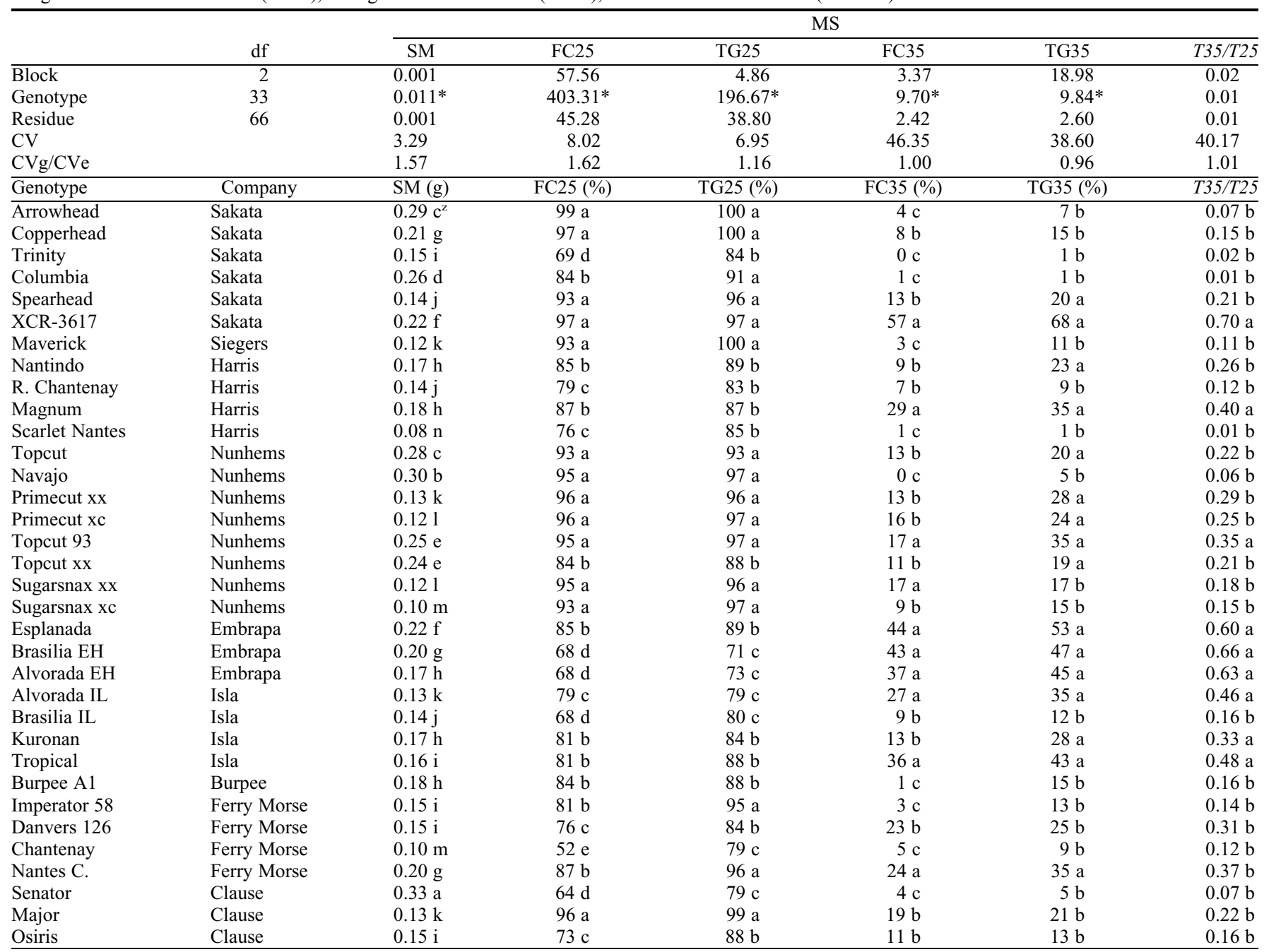

${ }^{2}$ Means within a column followed by different letters are significantly different at $P \leq 0.05$ according to Scott-Knott test.

* Significant at $P \leq 0.01$ by $\mathrm{F}$ test.

$\mathrm{CV}=$ phenotypic coefficient of variation; $\mathrm{CVg} / \mathrm{CVe}=$ relation between genetic and environmental $\mathrm{CV}$. 
Table 2. Analysis of variance for first germination count at $25{ }^{\circ} \mathrm{C}(\mathrm{FC} 25)$, total germination at $25{ }^{\circ} \mathrm{C}$ (TG25), first germination count at $35^{\circ} \mathrm{C}$ (FC35), total germination at $35{ }^{\circ} \mathrm{C}$ (TG35), and thermotolerance ratio $(T 35 / T 25)$ of 62 carrot accessions.

\begin{tabular}{lcccccc}
\hline & \multicolumn{7}{c}{ MS } \\
\cline { 2 - 7 } & df & FC25 & TG25 & FC35 & TG35 & T35/T25 \\
\hline Block & 2 & 1.02 & 0.40 & 2.00 & 0.10 & 0.005 \\
Genotype & 61 & $3.97^{*}$ & $0.89^{*}$ & $33.12^{*}$ & $32.90^{*}$ & $0.41^{*}$ \\
Residue & 122 & 0.44 & 0.21 & 0.64 & 0.55 & 0.009 \\
CV & & 7.91 & 5.02 & 15.77 & 13.78 & 16.15 \\
CVg/CVe & & 1.64 & 1.03 & 4.12 & 4.41 & 3.79 \\
Means-group 1 & & 79.88 & 83.49 & 56.83 & 61.50 & 0.75 \\
Means-group 2 & & 56.51 & 85.90 & 0.90 & 2.04 & 0.02 \\
\hline
\end{tabular}

Significant at $P \leq 0.01$ by $\mathrm{F}$ test.

$\mathrm{CV}=$ phenotypic coefficient of variation; $\mathrm{CVg} / \mathrm{CVe}=$ relation between genetic and environmental $\mathrm{CV}$.

$\sqrt{x}$ and the data of $35^{\circ} \mathrm{C}$ transformed by $(x+$ $0.50)^{1 / 2}$ to attend the normality presupposition. Analysis of variance and dissimilarity analysis based on Mahalanobis $\left(\mathrm{D}^{2}\right)$ Generalized Distances were performed with the Genes Program (Cruz, 2001), in which the dissimilarity matrix was transferred to the NTSYSpc Program (Rohlf, 2000) for the creation of a dendrogram based on the unweighted pair group method using the arithmetic averages clustering algorithm and determination of a cophenetic correlation coefficient between the matrix and the clus- ters (Rohlf and Sokal, 1981). An estimation of hypothetical ideal (Ideotype) was performed, in which the values for each character were considered as the highest among the accessions. For the accessions of each group, a means analysis was performed following the procedures of Scott and Knott (1974). Accession means for each group were calculated for each character, and a simple correlation among the characters was also performed. Analysis of relative importance of the characters for the accession dissimilarity was done following Singh (1981). The best genotypes for all characters for each group were chosen by using the selection index based on Pesek and Baker (1969).

\section{Germination and ethylene production at high temperature}

Plant material. From the first experiment, six genotypes were chosen according to their germination at high temperature and three classes were generated: thermosensitive ('Arrowhead' and 'Maverick'), intermediate ('Brasilia' and 'Magnum'), and thermotolerant ('XCR-3617' and PI 319858).

Germination test. Three replications of 25 seeds were incubated by using the same procedures as described previously.

Ethylene determination. Three replications of $0.1 \mathrm{~g}$ of dry seeds were placed on two layers of $3.0-\mathrm{cm}$ diameter germination paper (Anchor Paper Co.), which were placed in the base of 50-mL volume vials sealed with rubber septa (Fisher Scientific, Pittsburgh, PA). The seeds in the vials were moistened with $4 \mathrm{~mL}$ of distilled water and then incubated under the same conditions as the standard germination procedures. After $24 \mathrm{~h}$ of imbibition (at radicle protrusion), ethylene production was determined. A $1-\mathrm{mL}$ gas

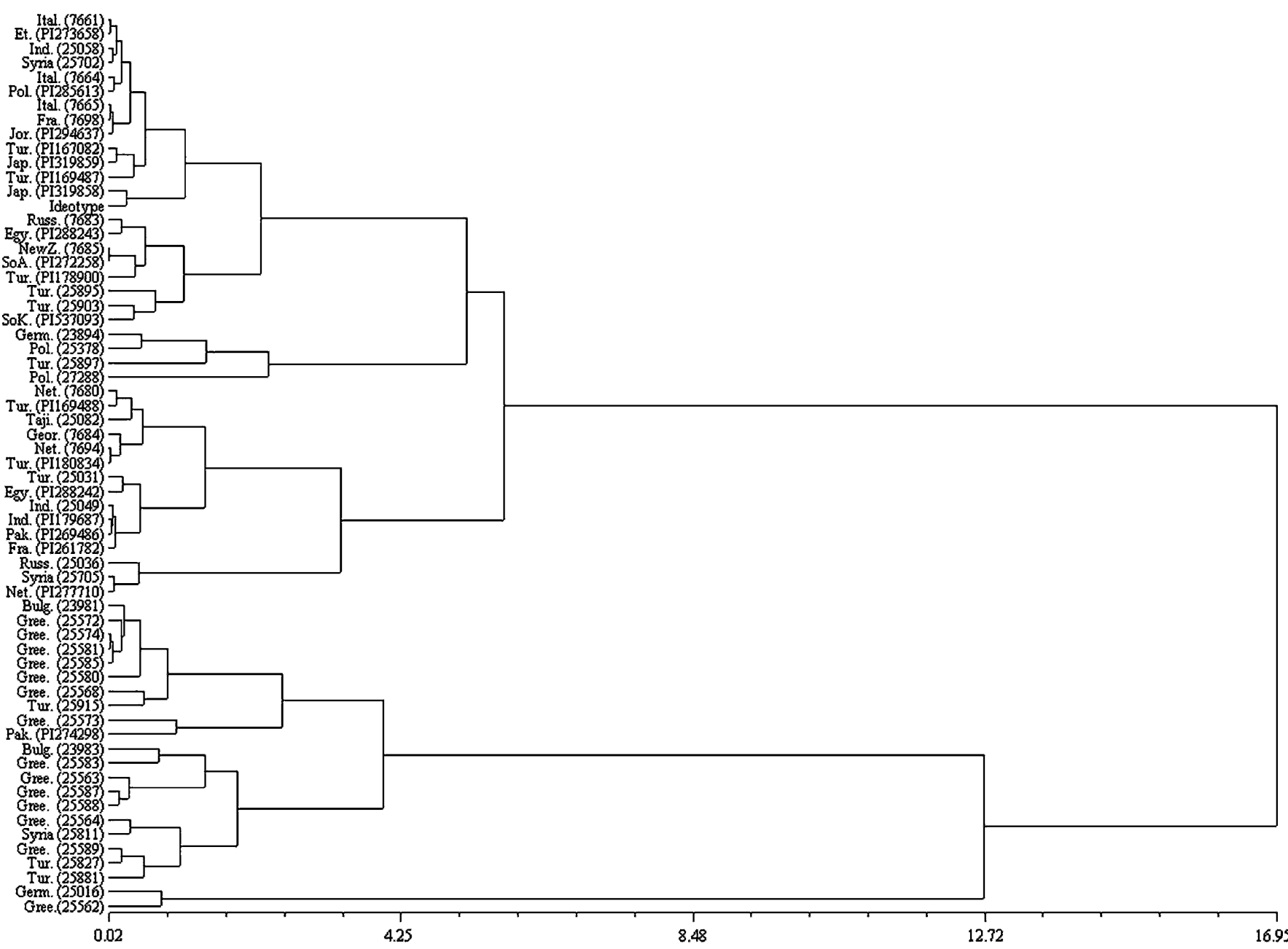

Fig. 1. Dendrogram of 66 carrot accessions based on germination characters generated from a Mahalanobis Similarity Matrix. Ital. $=$ Italy; Et. $=$ Ethiopia; Ind. $=$ India Pol. $=$ Poland; Fra. $=$ France; Jor $=$ Jordan; Tur. $=$ Turkey; Jap. $=$ Japan; Russ $=$ Russia $;$ Egy $=$ Egypt; NewZ. $=$ New Zealand; SoA = South Africa; SoK. $=$ South Korea; Germ. = Germany; Net. $=$ Netherlands; Taj. $=$ Tajikistan; Georg $=$ Georgia; Bulg. $=$ Bulgaria; Gree $=$ Greece. 
sample was withdrawn with a gas-tight hypodermic syringe (Fisher Scientific). Ethylene was assayed by using a Hewlett Packard Series II 5890 gas chromatograph (Hewlett Packard, Agilent Technologies, Foster City, CA) equipped with a flame ionization detector. The carrier gas was nitrogen. The oven, injector, and detector temperatures were 130, 110 , and $150{ }^{\circ} \mathrm{C}$, respectively.

Statistical analysis. The characters were transformed by $x^{1 / 2}$ to attain a normal distribution. A means analysis was performed following the procedures of Scott and Knott (1974), and simple correlations between character pairs were calculated.

\section{Results and Discussion}

Germination at high temperature of carrot seeds from different commercial cultivars. The commercial cultivars differed in most of the parameters examined (Table 1). No correlation between seed mass and seed germination at 25 and $35{ }^{\circ} \mathrm{C}$ was observed (data not shown). At $25{ }^{\circ} \mathrm{C}$, seed germination of most cultivars was above $80 \%$ (Table 1); however, the subtropical cultivars (Alvorada, Brasilia, Alvorada IL, and Chantenay) were lower. Nevertheless, those three cultivars, along with 'XCR-3617', had the greatest germination under high temperature and also the highest thermotolerance ratio (Table 1). Most other cultivars had reduced germination at $35{ }^{\circ} \mathrm{C}$. In another study, Carneiro and Guedes (1992) verified that 'Brasília' germinated $91 \%$ at $25^{\circ} \mathrm{C}$, whereas at $35{ }^{\circ} \mathrm{C}$, germination decreased to $47 \%$. Also, using the same cultivar, Nascimento and Pereira (2007) observed a higher reduction of germination at $35{ }^{\circ} \mathrm{C}$. In addition, 'Brasilia' carrot seeds that were previously incubated at 35 or $45^{\circ} \mathrm{C}$ lost their ability to germinate when transferred to 20 to $25{ }^{\circ} \mathrm{C}$, possibly as a result of an excessive increase in seed respiration and metabolic activities (Nascimento and Pereira, 2007) or a consequence of accelerated aging (Corbineau et al., 1994). Cultivars from the 'Brasilia' group are cultivated largely in tropical regions (Simon et al., 2007). For example, in Brazil, $\approx 80 \%$ of the carrot production area is sown with seeds from the 'Brasilia' group (Nascimento et al., 2003). As described previously, seeds from these cultivars generally have lower germination at optimal temperatures compared with imported commercial cultivars. In open-pollinated cultivars such as 'Brasilia', there is still high genetic diversity, which is one of the reasons why seed quality standards do not appear to be very well defined, leaving high variation in seed quality in terms of germination and vigor (Vieira et al., 2005). These traits may compromise crop establishment, especially under conditions such as high temperatures at imbibition.

Screening carrot germplasm for seed germination at high temperature. In this study, 63 of the initial 125 accessions were eliminated as a result of low germination or low vigor (data not shown). This was done to improve confidence levels in the statistical analysis. The analysis of variance from these results showed that all parameters were significantly different among the genotypes (Table 2) and the coefficients of variation were low, indicating good experimental precision, especially at $25^{\circ} \mathrm{C}$. The relation between the genetic and environmental coefficients of variation $(\mathrm{CVg} / \mathrm{CVe})$ were higher than 1, indicating predominance of genetic order effects, suggesting that satisfactory gains could be obtained from selection, especially at $35^{\circ} \mathrm{C}$.

According to the Mahalanobis Generalized Distance ( $\left.\mathrm{D}^{2}\right)$ (Mahalanobis, 1936), two large groups and a small group of two accessions near to the second group could be distinguished (Fig. 1). Our "Ideotype" (or ideal accession), a fictitious genotype originating from the higher values in each replication for each one of the characters, fit in the first group. The accession nearest to the "Ideotype" was PI 319858 from Japan. Thus, this PI was the most promising accession for good germination at both 25 and $35^{\circ} \mathrm{C}$. This accession germinated $95 \%$ under both temperature conditions and was considered ther- motolerant. The accession grouping is important, because crosses between accessions from different groups (more distinct) might lead to heterotic gains (Cruz and Regazzi, 1997; Falconer, 1981) and populations with broader genetic variation (Mohammadi and Prasanna, 2003).

Based on the mean values for each group, it was observed that the accessions from the first group had the highest means, especially at $35^{\circ} \mathrm{C}$ (Table 3 ). For the second group, the means did not have any significant differences at $25{ }^{\circ} \mathrm{C}$, because only three clusters were formed (Table 4). At $35{ }^{\circ} \mathrm{C}$, however, many accessions did not germinate or had low germination values. The accessions Ames 25915 from Turkey, PI 274298 from Pakistan, and Ames 23983 from Bulgaria had the highest germination at $35{ }^{\circ} \mathrm{C}$, although their values were lower than those from the first group.

A high correlation was observed between the first count and total germination, especially at $35^{\circ} \mathrm{C}$ (data not shown). For the same character under both temperature conditions, no significant correlations were observed,

Table 3. Mean comparison of first germination count at $25^{\circ} \mathrm{C}(\mathrm{FC} 25)$ and $35^{\circ} \mathrm{C}(\mathrm{FC} 35)$, total germination at $25{ }^{\circ} \mathrm{C}$ (TG 25) and $35^{\circ} \mathrm{C}$ (TG 35), and thermotolerance ratio (T35/T25) from carrot germplasm accessions in group 1.

\begin{tabular}{|c|c|c|c|c|c|c|}
\hline Genotypes & Origin & FC $25(\%)$ & TG $25(\%)$ & FC $35(\%)$ & TG $35(\%)$ & $T 35 / T 25$ \\
\hline Ames 7661 & Italy & $85 \mathrm{~h}^{\mathrm{z}}$ & $90 \mathrm{f}$ & $70 \mathrm{e}$ & $75 \mathrm{f}$ & $0.84 \mathrm{~b}$ \\
\hline Ames 7664 & Italy & $92 \mathrm{~d}$ & $93 \mathrm{~d}$ & $67 \mathrm{~g}$ & $67 \mathrm{k}$ & $0.72 \mathrm{c}$ \\
\hline Ames 7665 & Italy & $90 \mathrm{e}$ & $90 \mathrm{f}$ & $83 \mathrm{~b}$ & $87 \mathrm{~b}$ & $0.97 \mathrm{a}$ \\
\hline Ames 7680 & Netherlands & $72 n$ & $72 \mathrm{o}$ & $42 \mathrm{~s}$ & $48 \mathrm{u}$ & $0.69 \mathrm{c}$ \\
\hline Ames 7683 & Soviet Union & $78 \mathrm{k}$ & $80 \mathrm{k}$ & $45 \mathrm{r}$ & $50 \mathrm{t}$ & $0.63 \mathrm{~d}$ \\
\hline Ames 7684 & Georgia & $70 \mathrm{o}$ & $73 \mathrm{n}$ & $60 \mathrm{k}$ & $60 \mathrm{n}$ & $0.85 \mathrm{~b}$ \\
\hline Ames 7685 & New Zealand & $85 \mathrm{~h}$ & $88 \mathrm{~g}$ & $53 \mathrm{n}$ & $53 \mathrm{r}$ & $0.60 \mathrm{~d}$ \\
\hline Ames 7694 & Netherlands & $68 \mathrm{p}$ & $70 \mathrm{p}$ & $62 \mathrm{j}$ & $62 \mathrm{~m}$ & $0.89 \mathrm{~b}$ \\
\hline Ames 7698 & France & $88 \mathrm{f}$ & $88 \mathrm{~g}$ & $80 \mathrm{c}$ & $83 \mathrm{~d}$ & $0.95 \mathrm{a}$ \\
\hline Ames 23894 & Germany & $70 \mathrm{o}$ & $87 \mathrm{~h}$ & $8 \mathrm{~B}$ & $18 \mathrm{D}$ & $0.21 \mathrm{e}$ \\
\hline Ames 25031 & Turkey & $82 \mathrm{i}$ & $83 \mathrm{i}$ & $83 \mathrm{~b}$ & $85 \mathrm{c}$ & $1.03 \mathrm{a}$ \\
\hline Ames 25036 & Russia & $63 \mathrm{q}$ & $63 \mathrm{q}$ & $65 \mathrm{~h}$ & $70 \mathrm{i}$ & $1.15 \mathrm{a}$ \\
\hline Ames 25049 & India & $73 \mathrm{~m}$ & $77 \mathrm{~m}$ & $62 \mathrm{j}$ & 651 & $0.85 \mathrm{~b}$ \\
\hline Ames 25058 & India & $87 \mathrm{~g}$ & $88 \mathrm{~g}$ & $67 \mathrm{~g}$ & $67 \mathrm{k}$ & $0.76 \mathrm{c}$ \\
\hline Ames 25082 & Tajikistan & $63 \mathrm{q}$ & 720 & $40 \mathrm{t}$ & $47 \mathrm{v}$ & $0.71 \mathrm{c}$ \\
\hline Ames 25378 & Poland & $80 \mathrm{j}$ & $90 \mathrm{f}$ & $15 \mathrm{~A}$ & $22 \mathrm{C}$ & $0.25 \mathrm{e}$ \\
\hline Ames 25702 & Syria & $90 \mathrm{e}$ & $90 \mathrm{f}$ & $60 \mathrm{k}$ & 651 & $0.72 \mathrm{c}$ \\
\hline Ames 25705 & Syria & $62 \mathrm{r}$ & $62 \mathrm{r}$ & $48 \mathrm{q}$ & $52 \mathrm{~s}$ & $0.88 \mathrm{~b}$ \\
\hline Ames 25895 & Turkey & $68 \mathrm{p}$ & $88 \mathrm{~g}$ & $23 x$ & $33 \mathrm{z}$ & $0.38 \mathrm{e}$ \\
\hline Ames 25897 & Turkey & $72 \mathrm{n}$ & 781 & $20 \mathrm{z}$ & $30 \mathrm{~A}$ & $0.40 \mathrm{e}$ \\
\hline Ames 25903 & Turkey & $73 \mathrm{~m}$ & $87 \mathrm{~h}$ & $33 \mathrm{u}$ & $45 \mathrm{x}$ & $0.53 \mathrm{~d}$ \\
\hline Ames 27288 & Poland & $93 \mathrm{c}$ & $95 \mathrm{c}$ & $20 \mathrm{z}$ & $28 \mathrm{~B}$ & $0.30 \mathrm{e}$ \\
\hline PI 167082 & Turkey & $92 \mathrm{~d}$ & $95 \mathrm{c}$ & $80 \mathrm{c}$ & $80 \mathrm{e}$ & $0.84 \mathrm{~b}$ \\
\hline PI 169487 & Turkey & $92 \mathrm{~d}$ & $95 \mathrm{c}$ & $57 \mathrm{~m}$ & $60 \mathrm{n}$ & $0.63 \mathrm{~d}$ \\
\hline PI 169488 & Turkey & $73 \mathrm{~m}$ & $73 n$ & $52 \mathrm{o}$ & $55 \mathrm{q}$ & $0.75 \mathrm{c}$ \\
\hline PI 178900 & Turkey & $73 \mathrm{~m}$ & $87 \mathrm{~h}$ & $57 \mathrm{~m}$ & $60 \mathrm{n}$ & $0.70 \mathrm{c}$ \\
\hline PI 179687 & India & $78 \mathrm{k}$ & 781 & $63 \mathrm{j}$ & $67 \mathrm{k}$ & $0.86 \mathrm{~b}$ \\
\hline PI 180834 & Turkey & $68 \mathrm{p}$ & $70 \mathrm{p}$ & $63 \mathrm{j}$ & $67 \mathrm{k}$ & $0.96 \mathrm{a}$ \\
\hline PI 261782 & France & $78 \mathrm{k}$ & 781 & $70 \mathrm{e}$ & $73 \mathrm{~g}$ & $0.94 \mathrm{a}$ \\
\hline PI 269486 & Pakistan & 751 & 781 & 581 & $68 \mathrm{j}$ & $0.89 \mathrm{~b}$ \\
\hline PI 272258 & South Africa & $85 \mathrm{~h}$ & $88 \mathrm{~g}$ & $50 \mathrm{p}$ & $57 \mathrm{p}$ & $0.64 \mathrm{~d}$ \\
\hline PI 273658 & Ethiopia & $87 \mathrm{~g}$ & $88 \mathrm{~g}$ & $67 \mathrm{q}$ & $75 \mathrm{f}$ & $0.85 \mathrm{~b}$ \\
\hline PI 277710 & Netherlands & $60 \mathrm{~s}$ & $60 \mathrm{~s}$ & $50 \mathrm{p}$ & $58 \mathrm{o}$ & $0.98 \mathrm{a}$ \\
\hline PI 285613 & Poland & $92 \mathrm{~d}$ & $92 \mathrm{e}$ & $63 \mathrm{j}$ & $73 \mathrm{~g}$ & $0.80 \mathrm{c}$ \\
\hline PI 288242 & Egypt & $80 \mathrm{j}$ & $82 \mathrm{j}$ & $72 \mathrm{~d}$ & $72 \mathrm{~h}$ & $0.88 \mathrm{~b}$ \\
\hline PI 288243 & Egypt & $82 \mathrm{i}$ & $83 \mathrm{i}$ & $53 \mathrm{n}$ & $57 \mathrm{p}$ & $0.69 \mathrm{c}$ \\
\hline PI 294637 & Jordan & $85 \mathrm{~h}$ & $90 \mathrm{f}$ & $80 \mathrm{c}$ & $80 \mathrm{e}$ & $0.89 \mathrm{~b}$ \\
\hline PI 319858 & Japan & $95 \mathrm{~b}$ & $95 \mathrm{c}$ & $95 \mathrm{a}$ & $95 \mathrm{a}$ & $1.00 \mathrm{a}$ \\
\hline PI 319859 & Japan & $90 \mathrm{e}$ & $97 \mathrm{~b}$ & $68 \mathrm{f}$ & $73 \mathrm{~g}$ & $0.76 \mathrm{c}$ \\
\hline PI 537093 & South Korea & $85 \mathrm{~h}$ & $88 \mathrm{~g}$ & $30 \mathrm{v}$ & $45 \mathrm{x}$ & $0.51 \mathrm{~d}$ \\
\hline Ideotype & - & $100 \mathrm{a}$ & $100 \mathrm{a}$ & $95 \mathrm{a}$ & $95 \mathrm{a}$ & $0.95 \mathrm{a}$ \\
\hline
\end{tabular}

${ }^{2}$ Means within a column followed by different letters are significantly different at $P \leq 0.05$ according to Scott-Knott test. 
Table 4. Mean comparison of first germination count at $25^{\circ} \mathrm{C}(\mathrm{FC} 25)$ and $35^{\circ} \mathrm{C}(\mathrm{FC} 35)$, total germination at $25{ }^{\circ} \mathrm{C}(\mathrm{TG} 25)$ and $35{ }^{\circ} \mathrm{C}(\mathrm{TG} 35)$, and thermotolerance ratio $(T 35 / T 25)$ from carrot germplasm accessions in group 2.

\begin{tabular}{llccccc}
\hline Genotypes & Origin & FC25 $(\%)$ & TG25 $(\%)$ & FC35 (\%) & TG35 (\%) & $T 35 / T 25$ \\
\hline Ames 23981 & Bulgaria & $68 \mathrm{a}^{\mathrm{z}}$ & $88 \mathrm{a}$ & $0 \mathrm{~b}$ & $0 \mathrm{~b}$ & $0.00 \mathrm{~b}$ \\
Ames 25562 & Greece & $23 \mathrm{c}$ & $62 \mathrm{c}$ & $2 \mathrm{a}$ & $5 \mathrm{~b}$ & $0.07 \mathrm{a}$ \\
Ames 25563 & Greece & $32 \mathrm{c}$ & $82 \mathrm{~b}$ & $0 \mathrm{~b}$ & $2 \mathrm{~b}$ & $0.02 \mathrm{~b}$ \\
Ames 25564 & Greece & $52 \mathrm{~b}$ & $90 \mathrm{a}$ & $0 \mathrm{~b}$ & $2 \mathrm{~b}$ & $0.02 \mathrm{~b}$ \\
Ames 25568 & Greece & $87 \mathrm{a}$ & $95 \mathrm{a}$ & $0 \mathrm{~b}$ & $0 \mathrm{~b}$ & $0.00 \mathrm{~b}$ \\
Ames 25572 & Greece & $73 \mathrm{a}$ & $90 \mathrm{a}$ & $3 \mathrm{a}$ & $3 \mathrm{~b}$ & $0.04 \mathrm{~b}$ \\
Ames 25573 & Greece & $53 \mathrm{~b}$ & $100 \mathrm{a}$ & $0 \mathrm{~b}$ & $0 \mathrm{~b}$ & $0.00 \mathrm{~b}$ \\
Ames 25574 & Greece & $73 \mathrm{a}$ & $92 \mathrm{a}$ & $0 \mathrm{~b}$ & $0 \mathrm{~b}$ & $0.00 \mathrm{~b}$ \\
Ames 25580 & Greece & $77 \mathrm{a}$ & $85 \mathrm{a}$ & $0 \mathrm{~b}$ & $0 \mathrm{~b}$ & $0.00 \mathrm{~b}$ \\
Ames 25581 & Greece & $77 \mathrm{a}$ & $92 \mathrm{a}$ & $0 \mathrm{~b}$ & $0 \mathrm{~b}$ & $0.00 \mathrm{~b}$ \\
Ames 25583 & Greece & $52 \mathrm{~b}$ & $77 \mathrm{~b}$ & $0 \mathrm{~b}$ & $0 \mathrm{~b}$ & $0.00 \mathrm{~b}$ \\
Ames 25585 & Greece & $72 \mathrm{a}$ & $93 \mathrm{a}$ & $0 \mathrm{~b}$ & $0 \mathrm{~b}$ & $0.00 \mathrm{~b}$ \\
Ames 25587 & Greece & $35 \mathrm{c}$ & $85 \mathrm{a}$ & $0 \mathrm{~b}$ & $0 \mathrm{~b}$ & $0.00 \mathrm{~b}$ \\
Ames 25588 & Greece & $38 \mathrm{c}$ & $82 \mathrm{~b}$ & $0 \mathrm{~b}$ & $0 \mathrm{~b}$ & $0.00 \mathrm{~b}$ \\
Ames 25589 & Greece & $60 \mathrm{~b}$ & $85 \mathrm{a}$ & $0 \mathrm{~b}$ & $0 \mathrm{~b}$ & $0.00 \mathrm{~b}$ \\
Ames 25915 & Turkey & $83 \mathrm{a}$ & $95 \mathrm{a}$ & $3 \mathrm{a}$ & $7 \mathrm{a}$ & $0.07 \mathrm{a}$ \\
PI 274298 & Pakistan & $53 \mathrm{~b}$ & $97 \mathrm{a}$ & $5 \mathrm{a}$ & $12 \mathrm{a}$ & $0.12 \mathrm{a}$ \\
Ames 23983 & Bulgaria & $45 \mathrm{c}$ & $78 \mathrm{~b}$ & $3 \mathrm{a}$ & $8 \mathrm{a}$ & $0.11 \mathrm{a}$ \\
Ames 25811 & Turkey & $43 \mathrm{c}$ & $87 \mathrm{a}$ & $0 \mathrm{~b}$ & $3 \mathrm{~b}$ & $0.04 \mathrm{~b}$ \\
Ames 25827 & Turkey & $58 \mathrm{~b}$ & $88 \mathrm{a}$ & $2 \mathrm{a}$ & $2 \mathrm{~b}$ & $0.02 \mathrm{~b}$ \\
Ames 25881 & Turkey & $62 \mathrm{~b}$ & $80 \mathrm{~b}$ & $2 \mathrm{a}$ & $2 \mathrm{~b}$ & $0.02 \mathrm{~b}$ \\
Ames 25016 & Germany & $27 \mathrm{c}$ & $68 \mathrm{c}$ & $0 \mathrm{~b}$ & $0 \mathrm{~b}$ & $0.00 \mathrm{~b}$ \\
\hline
\end{tabular}

${ }^{\mathrm{z}}$ Means within a column followed by different letters are significantly different at $P \leq 0.05$ according to Scott-Knott test.

indicating that the accessions with the highest germination in one temperature were not necessarily the highest for the other temperature. By analyzing the relative contribution of each character on dissimilarity, it was verified that the total germination at $35{ }^{\circ} \mathrm{C}$ had the highest contribution (58\%) (Table 5). Thus, this character was considered the most important in the study; the characters of germination at $25{ }^{\circ} \mathrm{C}$ (FC25 and TG25) and the thermotolerance ratio had lower contributions to the distinction among accessions and thus were less useful during the evaluations.

The best genotypes for all characters in each group, according to the selection index based on desirable gains of Pesek and Baker (1969), were for Group 1: Ideotype, PI 178900 from Turkey, PI 319859 and PI 319858 from Japan, and PI 294637 from Jordan; and for Group 2: Ames 25564, Ames 25573, and Ames 25587 from Greece, PI 274298 from Pakistan, and Ames 25811 from Turkey. Consequently, the crosses between the best accessions of each group might generate superior progenies for those characters.

Six accessions (Ames 7665, Ames 7698, Ames 25031, PI 167082, PI 294637, and PI 319858 ) germinated above $80 \%$ at $35^{\circ} \mathrm{C}$ and were also identified as potential sources of thermotolerance (Table 3). Fifteen other accessions (Ames 7694, Ames 25031, Ames 25036, Ames 25049, Ames 25705, PI 167082, PI 179687, PI 180834, PI 261782, PI 269486, PI 273658, PI 277710, PI 288242, PI 294637, and PI 319858) had thermotolerance ratios T35/T25 of 0.85 or greater and were identified for further testing (Table 3). These accessions had low germination at $25{ }^{\circ} \mathrm{C}$; possibly they came from older seed stocks or had a higher incidence of dead seeds. It is difficult to separate genotypic differences in response to temperature from the effects of seed quality when seeds are not Scott-Knott test.

* Significant at $P \leq 0.01$ by $\mathrm{F}$ test.
Table 5. Relative contributions to the dissimilarity of 62 carrot accessions by the characters of first germination count at $25^{\circ} \mathrm{C}(\mathrm{FC} 25)$, total germination at $25^{\circ} \mathrm{C}$ (TG25), first germination count at $35{ }^{\circ} \mathrm{C}(\mathrm{FC} 35)$, total germination at $35{ }^{\circ} \mathrm{C}$ (TG35), and thermotolerance ratio (T35/T25).

\begin{tabular}{lc}
\hline Character & $\begin{array}{c}\text { Percent of contribution } \\
\text { to the dissimilarity }\end{array}$ \\
\hline FC25 & 14.86 \\
TG25 & 4.15 \\
FC35 & 22.35 \\
TG35 & 58.16 \\
T35/T25 & 0.47 \\
\hline
\end{tabular}

Accession dissimilarity calculated following Singh (1981).

different groups of temperature tolerance: the genotypes 'Arrowhead' and 'Maverick' germinated $32 \%$ and $43 \%$, respectively, and were considered thermosensitive; these two genotypes also had the lowest thermotolerance ratio (Table 6). The genotypes 'Brasilia' and 'Magnum' germinated $52 \%$ and $60 \%$, respectively, and were considered intermediate, whereas the genotypes PI 319858 and 'XPC-3617' germinated $85 \%$ and 93\%, respectively, and were considered thermotolerant.

Ethylene production during germination at $35^{\circ} \mathrm{C}$ was measured to determine possible differences among the thermosensitive and thermotolerant genotypes. In other species such as lettuce, the ability to produce ethylene during high temperature stress corresponded with their ability to germinate (Kozareva et al., 2006; Nascimento et al., 2000; Prusinski and Khan, 1990). In the present study, ethylene production during seed imbibition at high temperature was greater in thermotolerant genotypes than in thermosensitive genotypes (Table 6). In fact, high correlations were observed between first count at high temperature and ethylene production $(r=0.91)$, total germination at high temperature and ethylene production $(\mathrm{r}=$ 0.84 ), and thermotolerance ratio and ethylene production $(\mathrm{r}=0.97)$ (Table 7). Prusinski and Khan (1990) suggested ethylene production during seed germination at high temperature

Table 6. Analysis of variance and results for first germination count at $25{ }^{\circ} \mathrm{C}(\mathrm{FC} 25)$, total germination at $25{ }^{\circ} \mathrm{C}$ (TG25), first germination count at $35{ }^{\circ} \mathrm{C}(\mathrm{FC} 35)$, total germination at $35{ }^{\circ} \mathrm{C}(\mathrm{TG} 35)$, thermotolerance ratio $(T 35 / T 25)$, and ethylene $(\mathrm{ETH})$ production at $35^{\circ} \mathrm{C}$ of six carrot genotypes.

\begin{tabular}{|c|c|c|c|c|c|c|c|}
\hline & \multirow[b]{2}{*}{$\mathrm{df}$} & \multicolumn{6}{|c|}{ MS } \\
\hline & & $\mathrm{FC} 25$ & TG25 & FC35 & TG35 & $T 35 / T 25$ & Ethylene \\
\hline$\overline{\text { Block }}$ & 2 & 0.06 & 0.007 & 0.42 & 0.001 & 0.001 & 53.91 \\
\hline Genotype & 5 & $1.22 *$ & $1.14^{*}$ & $14.35 *$ & $7.30 *$ & $0.09 *$ & $260.58 *$ \\
\hline Residue & 10 & 0.04 & 0.03 & 0.41 & 0.45 & 0.007 & 35.70 \\
\hline $\mathrm{CV}$ & & 2.13 & 1.83 & 9.57 & 8.77 & 10.48 & 26.96 \\
\hline $\mathrm{CVg} / \mathrm{CVe}$ & & 3.10 & 3.48 & 3.38 & 2.25 & 1.89 & 1.45 \\
\hline Genotypes & & FC $25(\%)$ & TG $25(\%)$ & FC $35(\%)$ & TG $35(\%)$ & T35/T25 & $\overline{\mathrm{ETH}(\mu \mathrm{L} / \mathrm{g})}$ \\
\hline XPC-3617 & & $97 a^{z}$ & $97 \mathrm{a}$ & $85 \mathrm{a}$ & $93 \mathrm{a}$ & $0.96 \mathrm{a}$ & $450.8 \mathrm{a}$ \\
\hline PI 319858 & & $95 \mathrm{a}$ & $95 \mathrm{a}$ & $76 a$ & $85 \mathrm{a}$ & $0.90 \mathrm{a}$ & $448.2 \mathrm{a}$ \\
\hline Magnum & & $87 \mathrm{~b}$ & $87 \mathrm{~b}$ & $49 \mathrm{~b}$ & $60 \mathrm{~b}$ & $0.70 \mathrm{a}$ & $334.5 \mathrm{a}$ \\
\hline Brasilia & & $68 \mathrm{c}$ & $71 \mathrm{c}$ & $47 \mathrm{~b}$ & $52 \mathrm{~b}$ & $0.74 \mathrm{a}$ & $420.5 \mathrm{a}$ \\
\hline Maverick & & $93 \mathrm{a}$ & $100 \mathrm{a}$ & $16 \mathrm{c}$ & $43 \mathrm{c}$ & $0.43 \mathrm{~b}$ & $77.3 \mathrm{~b}$ \\
\hline Arrowhead & & $99 \mathrm{a}$ & $100 \mathrm{a}$ & $19 \mathrm{c}$ & $32 \mathrm{c}$ & $0.32 \mathrm{~b}$ & $36.5 \mathrm{~b}$ \\
\hline
\end{tabular}

${ }^{\mathrm{z}}$ Means within a column followed by different letters are significantly different at $P \leq 0.05$ according to

$\mathrm{CV}=$ phenotypic coefficient of variation; $\mathrm{CVg} / \mathrm{CVe}=$ relation between genetic and environmental $\mathrm{CV}$. 
Table 7. Correlation between first germination count at $25^{\circ} \mathrm{C}(\mathrm{FC} 25)$ and $35^{\circ} \mathrm{C}(\mathrm{FC} 35)$, total germination at $25^{\circ} \mathrm{C}(\mathrm{TG} 25)$ and $35^{\circ} \mathrm{C}(\mathrm{TG} 35)$, thermotolerance ratio $(\mathrm{T} 35 / \mathrm{T} 25)$, and ethylene production at $35^{\circ} \mathrm{C}$ of six carrot genotypes.

\begin{tabular}{|c|c|c|c|c|c|c|}
\hline & $\mathrm{FC} 25$ & TG25 & FC35 & TG35 & $T 35 / T 25$ & Ethylene \\
\hline \multicolumn{7}{|l|}{ FC25 } \\
\hline TG25 & $0.97 * *$ & & & & & \\
\hline FC35 & 0.05 & -0.11 & & & & \\
\hline TG35 & 0.18 & 0.05 & $0.97 * *$ & & & \\
\hline$T 35 / T 25$ & -0.15 & -0.28 & $0.97 * *$ & $0.94 * *$ & & \\
\hline Ethylene & -0.36 & -0.50 & $0.91 *$ & $0.84^{*}$ & $0.97 * *$ & \\
\hline
\end{tabular}

**Significant at $P \leq 0.01 ;$ *significant at $P \leq 0.05$.

be used as a criterion to select thermotolerant lettuce cultivars. In another study, Nascimento et al. (2000) observed that ethylene production in thermotolerant lettuce genotypes was higher than in the thermosensitive genotypes; these authors also verified a high correlation between ethylene production and lettuce seed germination at high temperature. A relationship between carrot seed germination at high temperature and an increase in ethylene production during radicle protrusion was also established in this study. The amount of ethylene production might be developed as a screen for carrot thermotolerant genotypes. However, only seeds with high viability should be used.

Seed treatments (i.e., seed priming) (Cantliffe and Elballa, 1994) or cultural practices that improve seed viability and quality may also help circumvent carrot thermodormancy problems. Consequently, approaches optimizing seed quality during seed production in the field (Rubatzky et al., 1999) and the selection of superior, thermotolerant progenies during breeding programs (Vieira et al., 2005) should be used. Genotypic variability for germination at high temperatures has been detected in other species (Argyris et al., 2005; Pallais et al., 1987), and germination at sub- or supraoptimal temperatures may be a desirable trait for incorporating into carrot breeding programs. High genetic variability observed among progenies from the 'Brasilia' carrot group suggested that simple breeding methods may be applied to increase physiological seed quality (Vieira et al., 2005).

\section{Conclusions}

The ability of carrot seeds to germinate at high temperatures is genotype-dependent, and the thermotolerant genotypes we identified may be useful for incorporating thermotolerance traits into breeding programs. A relationship between thermotolerance and ethylene production during carrot seed germination at high temperature was also observed, and studies should be carried out to better understand the role of ethylene in carrot seed germination at supraoptimal temperatures.

\section{Literature Cited}

Abeles, F.B., P.W. Morgan, and M.E. Saltveit, Jr. 1992. Ethylene and plant biology. 2nd Ed. Academic Press, San Diego, CA.

Argyris, J., M.J. Truco, O. Uchoa, S.J. Knapp, D.W. Still, G.M. Lenssen, J.W. Schut, R.W. Michelmore, and K.J. Bradford. 2005. Quantitative trait loci associated with seed and seed- ling traits in Lactuca. Theor. Appl. Gen. 111:1365-1376

Association of Official Seed Analysts. 1993. Rules for testing seeds. J. Seed Tech. 16:1-113.

Bradford, K.J., D. Côme, and F. Corbineau. 2007. Quantifying the oxygen sensitivity of seed germination using a population-based threshold model. Seed Sci. Res. 17:33-43.

Cantliffe, D.J. and M. Elballa. 1994. Improved germination of carrot at stressful high temperature by seed priming. Proc. Flo. Sta. Hort. Soc. 107:121-128.

Carneiro, J.W.P. and T.A. Guedes. 1992. Influência da temperatura no desempenho germinativo de sementes de cenoura (Daucus carota $\mathrm{L}$.), avaliada pela função de distribuição de Weibull. Rev. Bras. Sem. 14:207-213.

Corbineau, F., M.A. Picard, and D. Come. 1994. Effects of temperature, oxygen and osmotic pressure on germination of carrot seeds: Evaluation of seed quality. Acta Hort. 354:9-16.

Cruz, C.D. 2001. Programa Genes: Aplicativo computacional em genética e estatística. Viçosa, Editora UFV.

Cruz, C.D. and A.J. Regazzi. 1997. Divergência genética. In: Cruz, C.D. and A.J. Regazzi (eds.). Métodos biométricos aplicados ao melhoramento genético. Viçosa, UFV: Imprensa Universitária 6:287-324.

Day-Rubenstein, K., M. Smale, and M.P. Widrlechner. 2006. Demand for genetic resources and the U.S. National Plant Germplasm System. Crop Sci. 46:1021-1031.

Ellis, R.H., G. Simon, and S. Covell. 1987. The influence of temperature on seed germination rate in grain legumes, III. A comparison of five faba bean genotypes at constant temperature using a new screening method. J. Expt. Bot. 38:10331044.

Falconer, D.S. 1981. Introdução à genética quantitativa. Tradução de Silva MA e Silva JC. Viçosa: UFV, Impr. Univ.

Gray, D., J.R.A. Steckel, J. Dearman, and P.A. Brocklehurst. 1988. Some effects of temperature during seed development on carrot (Daucus carota L.). Ann. Appl. Bio. 112:367-376.

Heydeker, W. 1972. Vigor, p. 209-252. In: Roberts, E.H. (ed.). Viability of seeds. Syracuse University Press, Syracuse, NY.

Kozareva, I., D.J. Cantliffe, R.T. Nagata, and H.J. Klee. 2004. New support for the involvement of ethylene in lettuce germination at supraoptimal temperature. Acta Hort. 631:31-37.

Kozareva, I., D.J. Cantliffe, R.T. Nagata, and P.J. Stoffella. 2006. High maturation temperature of lettuce seeds results in increased ethylene production and germination at elevated temperatures. J. Amer. Soc. Hort. Sci. 131:564-570.

Lilliefors, H.W. 1967. On the Kolmogorov-Smirnov test for normality with mean and variance unknown. J. Amer. Sta. Assoc. 62:399-402.

Mahalanobis, P.C. 1936. On the generalized distance in statistics. Proc. Nat. Inst. Sci. India 12:49-55.

Mohammadi, S.A. and B.M. Prasanna. 2003. Analysis of genetic diversity in crop plants. Salient statistical tools and considerations. Crop Sci. 43:1235-1248

Nascimento, W.M., D.J. Cantliffe, and D.J. Huber. 2000. Thermotolerance in lettuce seeds: Association with ethylene and endo- $\beta$-mannanase. J. Amer. Soc. Hort. Sci. 125:518-524.

Nascimento, W.M., D.J. Cantliffe, and D.J. Huber. 2004 . Ethylene evolution and endo- $\beta$-mannanase activity during lettuce seed germination at high temperature. Sci. Agr. 61:156-163.

Nascimento, W.M., D.J. Cantliffe, and D.J. Huber. 2005. Seed aging affects ethylene production and endo- $\beta$-mannanase activity during lettuce seed germination at high temperature. Seed Sci. Technol. 33:11-17.

Nascimento, W.M. and R.S. Pereira. 2007. Preventing thermo-inhibition in carrot by seed priming. Seed Sci. Tech. 35:503-506.

Nascimento, W.M., J.V. Vieira, and M.C. Alvares. 2003. Physiological maturity of carrot seeds cV. Alvorada under tropical conditions. Acta Hort. 607:49-51.

Pallais, N., Z. Huaman, and S. Hopmans. 1987. Screening true potato seeds of native Andean cultivars for germinability under high temperatures. European Association of Potato Research, 10th Triennial Conference, Aalborg, Denmark, p. 292-293.

Pereira, R.S., W.M. Nascimento, and J.V. Vieira. 2007. Germinação e vigor de sementes de cenoura sob condições de altas temperaturas. Hort. Bras. 25:215-219.

Perkins-Veazie, P. and D.J. Cantliffe. 1984. Need for high-quality seed for effective priming to overcome thermodormancy in lettuce. J. Amer. Soc. Hort. Sci. 109:368-372.

Pesek, J. and R.J. Baker. 1969. Desired improvement in relation to selected indices. Can. J. Plant Sci. 49:803-804.

Prusinski, J. and A.A. Khan. 1990. Relationship of ethylene production to stress alleviation in seeds of lettuce cultivars. J. Amer. Soc. Hort. Sci. 115:294-298.

Rohlf, F.J. 2000. NTSYSpc numerical taxonomy and multivariate analysis system. Version 2.1. Exeter Software, Setauket, NY.

Rohlf, F.J. and R.R.N. Sokal. 1981. Comparing numerical taxonomic studies. Syst. Zool. 30:459-499.

Rubatzky, V.E., C.F. Quiros, and P.W. Simon. 1999. Carrot and related vegetable Umbelliferae. CABI Publishing, New York, NY.

Scott, A.J. and M.A. Knott. 1974. Cluster analysis methods for grouping means in the analysis of variance. Biometrics 30:507-512.

Senthil-Kumar, M., K. Ganesh, V. Srikanthbabu, and M. Udayakumar. 2007. Assessment of variability in acquired thermotolerance: Potential option to study genotypic response and the relevance of stress genes. J. Plant Physiol. 164:111-125.

Simon, P.W., R.E. Freeman, J.V. Vieira, L.S Boiteux, M. Briard, T. Nothnagel, B. Michalik, and Y.C. Kwon. 2007. Carrot, p. 315-345. In: Prohens, J. (ed.). Handbook of plant breeding. Vol. 1. Springer, Berlin, Germany.

Singh, D. 1981. The relative importance of characters affecting genetic divergence. Indian $\mathrm{J}$. Gen. Plant Breed. 41:237-245.

Sung, Y., D.J. Cantliffe, and R.T. Nagata. 1998. Seed developmental temperature regulation of thermotolerance in lettuce. J. Amer. Soc. Hort. Sci. 123:700-705.

Vieira, J.V., C.D. Cruz, W.M. Nascimento, and J.E.C. Miranda. 2005. Seleção de progênies de meio-irmãos de cenoura baseada em características de sementes. Hort. Bras. 23:44-47.

Vierling, E. 1991. The roles of heat shock proteins in plants. Ann. Rev. Plant Physiol. Plant Mol. Biol. 42:579-620. 